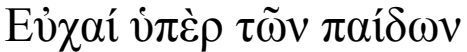

\section{AUGUSTUS AND SOME HONORS FOR GAIUS AND LUCIUS IN THE ROMAN EAST}

\begin{abstract}
Summary: Augustus felt an urgent need to justify the honours conferred on his adoptive sons, Gaius and Lucius Caesar, and the positions attributed to them, before the period of time provided by law, on the basis of merit (... he never recommended his sons for office without adding "If they be worthy of it", Suet. Aug. 56). The aim of this paper is to examine some epigraphic documents showing how the principes iuventutis were celebrated by eastern communities adhering to the dynastic model identified through the political choices of the princeps at a time when Gaius and Lucius' very young age suggested more caution in appointing them for public honors.
\end{abstract}

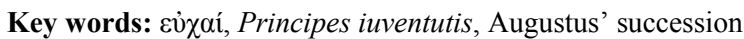

Augustus' plans concerning his succession were marked, as commonly known, by different phases and attempts. ${ }^{1}$ A primary role was given to Gaius and Lucius, ${ }^{2}$ sons of Giulia and Agrippa, who had become Caesars after their adoption per assem et libram in $17 \mathrm{BC}^{3}$ - the well-known year when ludi saeculares were celebrated - when

${ }^{1}$ It is not possible to refer to such a wide literature on this topic. For all legal aspects, see DE MARTino, F.: Storia della Costituzione Romana. IV 1. Napoli 1974, and the related literature. See also PANI, M.: Tendenze politiche della successione al principato di Augusto. Bari 1979; HURLET, F. - DELLA RosA, A.: Un quindicennio di ricerche su Augusto. Un bilancio storiografico. SCO 55 (2009) 169-211. More recently, OSGOOD, J.: Suetonius and the Succession to Augustus. In GIBSON, A. G. G. (ed.): The JulioClaudian Succession. Reality and Perception of the "Augustan Model". Leiden-Boston 2013, 19-40.

${ }^{2}$ Sources in $P I R^{2}$ I, 216 and 222. See GARDTHAuSEN, V.: Gaius Caesar. In $R E$ X (1918) 424 428; Lucius Caesar. Ibid. 472-473; NENCI, G.: Gaio e Lucio Cesari nella politica augustea. In NENCI, G.: Introduzione alle guerre persiane ed altri saggi di storia antica. Pisa 1958, 311-347; HURLET, F.: Les collègues du prince sous Auguste et Tibère. Roma 1997, 113-141; BORCHHARDT, J.: Der Fries vom Kenotaph für Gaius Caesar in Lymira. Wien 2002, 91-107; SegENNI, S.: I Decreta Pisana. Autonomia cittadina e ideologia imperiale nella Colonia Opsequens Iulia Pisana. Bari 2011, 25-49.

${ }^{3}$ Suet. Aug. 64. 1; Vell. 2. 96; Dio. 54. 18. 1; Zon. 10. 34. Augustus adopted Gaium and Lucium at home, privately buying them from their father by a symbolic sale. This form of purchase consisted in thrice touching a balance (libra) with a penny (as), in the presence of the praetor. See FAYER, C.: La familia romana. Aspetti giuridici ed antiquari. Vol. I. Roma 1994, 337-338. 
Gaius was 3 years old and Lucius was an infant. Their brief lives have been quite accurately documented despite the limited number of historiographical data. The events following their deaths explain historians' limited interest in these public figures: during

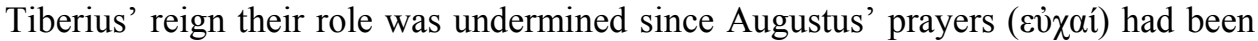
focused on them while he was forced to chose Livia's first child only and after an atrox fortuna had prematurely taken Gaius and Lucius away from life and his love. ${ }^{4}$ This is how it went according to the incipit of Augustus' last will according to Suetonius. As testified also by Velleius, Tacitus and Cassius Dio, the cursus steps of various figures close to the princeps were subject to accelerations, a slowing down or a decline in relation to the careers of the two sons/grandchildren, which were parallel despite the three-year difference between them. Augustus held the twelfth and thirteenth Consulate, respectively in 5 and $2 \mathrm{BC}$, when the Caesares were deducti in forum, as though he wanted to personally introduce them to the political arena. They were successors to his office ( $\delta i \alpha ́ \delta o \chi 01 \tau \tilde{\eta} \varsigma \alpha \hat{\rho} \chi \tilde{\eta} \varsigma$ ), according to Cassius Dio's definition, ${ }^{5}$ and they clearly benefited from the reduction of the time limits provided by law to take specific public offices. ${ }^{6}$ The Senate and the Roman people made them consulsdesignate, each in his fifteenth years, before they had yet laid aside the dress of boyhood (necdum posita puerili praetexta), as Tacitus argues, ${ }^{7}$ so that they would enter that magistracy after five years, and the Senate decreed that from the day on which they were introduced to the forum, they would be included in public councils. ${ }^{8}$ The entire body of Roman knights elected them principes iuventutis, a title qualifying them as leaders of the Roman armed youth and gave them silver shields and spears. ${ }^{9}$ The name iuventus indicated the whole equestrian order, ${ }^{10}$ and a parallel is inevitably drawn with the title of princeps senum bestowed on Augustus for life. The interrelation of

${ }^{4}$ Suet. Tib. 23: Testamenti initium fuit: Quoniam atrox fortuna Gaium et Lucium filios mihi eripuit, Tiberius Caesar mihi ex parte dimidia et sextante heres esto.

${ }^{5}$ Dio. 54. 18: Augustus ... not waiting for them to become men, but appointing them then and there successors to his office, in order that fewer plots might be formed against him. See SWAN, P. M.: The Augustan Succession. An Historical Commentary on Cassius Dio's Roman History, Books 55-56 (9 BC-AD 14). Oxford 2004.

${ }^{6}$ In $13 \mathrm{BC}$, Gaius helped Tiberius, who was consul, to organize the games for Augustus' return (Dio. 54. 27. 1) and took part in the Trojan lusus (Dio. 54. 26. 1); in 8 he accompanied Augustus to Gallia and was introduced to the Renan legions (Dio. 55. 6. 4), while Lucius was deductus in forum (Suet. Aug. 26. 2). From the age of fifteen they started a political and military internship: in 4 BC Gaius participated in a council to discuss Herod's inheritance (Ioseph. Ant. Jud. 17. 9. 5); in 2 they were both duoviri aedi dedicandae consulari potestate during the dedication of the Temple of Mars Ultor (Dio. 55.10. 5; CIL VI 40311).

${ }^{7}$ Tac. Ann. 1. 3; Dio 55. 9. 2-3.

${ }^{8}$ Res gestae divi Augusti 14: Filios meos, quos iuvenes mihi eripuit fortuna, Gaium et Lucium Caesares honoris mei caussa senatus populusque Romanus annum quintum et decimum agentis consules designavit, ut eum magistratum inirent post quinquennium, et ex eo die quo deducti sunt in forum ut interessent consiliis publicis decrevit senatus. Equites autem Romani universi principes iuventutis utrumque eorum parmis et hastis argenteis donatum appellaverunt. See Suet. Aug. 26. 2; Dio 55. 9. 2; 55. 100. 9.

${ }^{9}$ See VAssilieOU, A.: Caius ou Lucius Caesar proclamé principes iuventutis par l'ordre équestre. In Walter, H.: Hommages à L. Lerat. Paris 1984, 827-840; DEMOUGIN, S.: L'ordre équestre sous le Julio-Claudiens. Rome 1988, 258-259.

${ }^{10}$ It appears that Gaius was given the title of sevir equitum Romanorum, an officer responsible for leading ludi Sevirales o Martiales before the Temple of Mars Ultor (Zon. 10. 35). 
their actions and the constant analogy of their cursus are associated with an image of brotherly harmony. ${ }^{11}$ Augustus expressed his desire and intention to transfer (traducere) his own statio to both his sons in a letter written for his sixty-fourth birthday and addressed to Gaius away from Rome for the first time on an official mission aimed at restoring the Roman influence in Armenia. ${ }^{12}$ However, he did not want such facilitations of their cursus to be misinterpreted, exploited or interpreted as an imposition on the authorities in charge of appointing magistrates. Suetonius explains that he never recommended his sons for office without adding "If they be worthy of it". ${ }^{13}$ Thus, on a formal level, their merits, rather than their relations/kinship, were the prerequisites for a rapid career, even though in the Res Gestae ${ }^{14}$ the princeps, recalling his sons "whom fortune snatched away from me in their youth" (quos iuvenes eripuit fortuna), as he said, while listing the honours bestowed on them, by the will of the senatus populusque romanus and equites romani universi respectively, was induced to add that they had been honoris mei caussa.

Augustus dynastic ambitions emerge clearly from the detailed publicizing through titulos et imagines and public appearances of his two sons. The currency emissions coins of western mints portray them together in their specific office of principes iuventutis, as well as with parma and hasta, ${ }^{15}$ with the lituus, the curved staff of an augur and with the simpulum, the sacrificial ladle, symbols of their religious roles. It is only in their religious roles that a difference can be found: Gaius was pontifex ${ }^{16}$ whereas Lucius was augur. Such diversity has been related in the past to a possible lack of similar religious positions. As commonly known, religious figures were not "appointed" since the college's members nominated each other. It is therefore likely that the two Caesars could not take the same office due to a lack of available seats in the two colleges. Between $6 \mathrm{BC}$, the year of Gaius' pontificate, and $2 \mathrm{AD}$, the year of Lucius' death, no further offices became available in the pontifical college, which is why Lucius could not become pontifex. The same can be said for Gaius who could not become augur for the same reasons. ${ }^{17}$ It has also been argued that, from a completely different perspective, the attribution of two different religious offices had been explicitly planned by Augustus, who wanted to emphasize - quite clearly - the directives and guidelines of his religious reform, including, on the one hand, a return to the ancient myths related to the Romulan line and, on the other hand, the inclusion of new

${ }^{11}$ Sen. ad Polyb. 154; Dio. 55. 100. 9.

${ }^{12}$ Gell. NA 15. 7. 3: Deos autem oro ut, mihi quantumcumque superest temporis, id salvis nobis

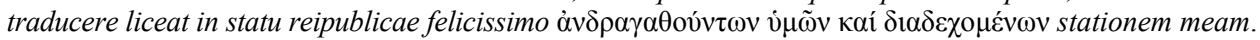
See BÉRANGer, J.: Pour une definition du principat: Auguste dans Aule Gelle 15, 7, 3. In BÉRANGER, J.: Principatus. Études de notions et d'histoire politiques dans l'Antiquité gréco-romaine. Genève 1973, 153-163; Koestermann, E.: Statio principis. In Kloft, H. (Hrsg.): Ideologie und Herrschaft in der Antike. Darmstadt $1980^{3}, 388-415$.

${ }^{13}$ Suet. Aug. 56: ... numquam filios suos populo commendavit ut non adicieret: si merebuntur.

${ }_{15}^{14}$ Res g. d. A. 14. 1.

${ }^{15}$ REBECCHI, F.: Per l'iconografia della transvectio equitum. Altre considerazioni e nuovi documenti. In Demougin, S. - DeviJver, H. - RAEPSAET Charlier, M.T. (éd.): L'ordre équestre. Histoire d'une aristocratie (II siècle av. J.C. - III siècle ap. J.C.). Rome 1999, 191-214, esp. 192 ss.

${ }^{16}$ Probably in 6 BC (Dio. 55. 9. 4). Among several epigraphic references, see CIL XI 314.

${ }^{17}$ On such interpretation see NENCI (n. 2) 316 ss. 
elements from the Graecus ritus. Augustus'intention in this sense was expressed, according to an archaeological interpretation, ${ }^{18}$ through the figurative cycle of the Ara Pacis, where the two children were assimilated and almost identified with AscaniusIulus and with Romulus. Gaius, portrayed as Ascanius-Iulus in the southern procession of the Ara Pacis, taken to Lavinium's augurium, was the symbol of the gens Iulia's lineage from Aeneas' descent, while Lucius, was like Romulus, portrayed through the miracle of the twins breast-fed by the wolf. Gaius Ascanius-Iulus would have become pontifex, that is to say he would have become a member of the sacerdotal college connected to Lavinium-myth (Aeneas had disembarked at Lavinium, as known, taking the Penates); Lucius-Romulus would have been appointed to the augural college, whose foundation dated back to Romulus, the first conditor urbis. Augurate and pontificate would therefore relate Lucius and Gaius to the first founder of Rome and to the son of the goddess Venus, celebrating the most genuine Roman tradition while emphasizing an ideal connection between the gens Iulia and its Trojan progeny. ${ }^{19}$

Portraits were another common tool of the official propaganda: artists of the time represented Gaius and Lucius as extremely similar to their adoptive father, which is why nowadays it is very difficult to determine the identity of certain portraits, ${ }^{20}$ despite the possible resemblance of the two children since, if we rely on Macrobius' interpretation, ${ }^{21}$ according to whom every time Augustus observed all his grand children, noting their resemblance with Agrippa, he ashamed to doubt the modesty of her daughter (dubitare de pudicitia filiae erubescebat). Besides their physical resemblance, Augustus tended to emphasize their "spiritual resemblance". This is testified to by the dedication placed on the Colonia Opsequens Iulia Pisana commemorating the death of Gaius, defined as iam designatus iustissimus ac simillimus parentis sui virtutibus princeps. $^{22}$ Tacitus provides an opposing interpretation ${ }^{23}$ regarding public opinion on the political and institutional context of the princedom on the day of Augustus' funeral,

${ }^{18}$ Moretti, G.: Ara Pacis. Roma 1948, 264 ss.

${ }^{19}$ MORETTI (n. 18) 267; ZANKER, P.: Augusto e il potere delle immagini. Trad. it. di F. Cuniberto. Torino 1989, 215-224, 231-233; MASTROCINQUE, A.: I sacerdoti di Apollo e il culto imperiale. In URSO, G. (a cura di): Sacerdos. Figure del sacro nella società romana. Atti del Convegno Internazionale Cividale del Friuli 26-28 settembre 2012. Pisa 2014, 223-238.

${ }^{20}$ Pollini, J.: The Portraiture of Gaius and Lucius. New York 1987; Pollini, J.: From Republic to Empire: Rhetoric, Religion and Power in the Visual Culture of Ancient Rome, Norman (Oklahoma) 2012, 400 ss.; BosCHUNG, D.: Die Bildnistypen der iulisch-claudischen Kaiserfamilie: ein Kritischer Forschungsbericht. JRA 6 (1993) 39-79; BoschUNG, D.: Gens Augusta. Untersuchungen zu Aufstellung, Wirkung und Bedeutung der Statuengruppen des julisch-claudischen Kaiserhauses [Monumenta Artis Romanae XXXII]. Mainz am Rhein 2002; BALTY, J.-CH.: C. et L. César. Les points forts d'une iconographie. In CHRISTOL, M. - DARDE, D.: L'Expression du pouvoir au début de l'Empire: autour de la Maison Carrée à Nîmes. Paris 2009, 59-67; Rosso, E.: Les hommages rendus à Caius et Lucius Caesar dans les provinces gauloises et alpines. In CHRISTOL-DARDE 97-110.

${ }^{21}$ Macr. Sat. 2, 5, 3.

${ }^{22}$ CIL XI 1421. See Marotta D’AgatA, A. R.: Decreta Pisana (CIL XI 1420-1421). Edizione critica, traduzione e commento, Pisa 1980. As indicated by BERANGER: Principatus (n. 12) 255, the peculiar position of the adjective designatus before the noun princeps, referring to Gaius, should not be interpreted as an official appointment, rather as an example of affective language.

${ }^{23}$ Tac. Ann. 1. 8-10. 
according to which Tiberius would have been chosen as a successor, not because of affection or public interest, but because Augustus was seeking glory for himself through the worst comparison (comparatio deterrima).

Roman cives and eastern subjects proved to be very sensitive to stimulations and messages of Augustan propaganda, almost preceding even the princeps in designating Gaius and Lucius for his succession. The number of dedications devoted to them is surprising, particularly taking into account their brief lives. Most inscriptions can be dated back to an extremely limited chronological period, during which the two Caesars were qualified in the positions that they held after their official introduction into the political arena in $5 \mathrm{BC}$, in Gaius' case, and $2 \mathrm{BC}$ for Lucius. They died respectively in 2 and $4 \mathrm{AD}$. Almost all funeral dedications were placed immediately after their death because, since Tiberius' adoption took place in $4 \mathrm{AD}$, only after both of them had died did it not seem dangerous to show excessive regret towards those who had been the main obstacle for his political career. Such abundant inscriptions can thus be considered relevant to a period between $5 \mathrm{BC}$ and $4 \mathrm{AD}$.

The tone of dedications in western territories are very diverse ${ }^{24}$ compared to the eastern area of the Empire. Western epigraphic dedications, which are well known and have been thoroughly examined, in most cases show only the titles of these two Caesars, qualified as Augustus' sons, sometimes as grandchildren of the Divus Iulius, the first as consul and pontifex, the second as consul designatus and augur, and both principes iuventutis. Dedications placed by $\pi$ ó $\lambda \varepsilon 1 \varsigma$, кoเvó or single politai from the eastern area are richer and more significant; more dedications have been devoted to Gaius probably because of his presence in Greece, Syria, Asia Minor, and Armenia where he was given an imperium proconsulare while he was still consul designatus in $1 \mathrm{BC}^{25}$

${ }^{24}$ SIDARI, D.: Studi su Gaio e Lucio Cesari. AIV 138 (1979-1980) 275-302; CENERINI, G.: Gaio e Lucio Cesari, nipoti e successori di Augusto: la documentazione occidentale. RSA 40 (2010) 109-136. See also CONTI, S.: Dinastia giulio-claudia a Roselle: una serie di dediche imperiali in Etruria. AFLS 18 (1997) 101-128.

${ }^{25}$ Tac. Ann. 2. 4. 2; Zon. 10. 36. The decree of the city of Messene is particularly significant in this sense $(A E$ 1967, $458=S E G$ XXIII (1968) nr. 206) since it was in honour of Publius Cornelius Scipio quaestor pro praetore, among the numerous expressions of reverence and loyalty to the Emperor. Publius Scipio, being endowed with unsurpassed goodwill towards Augustus and his whole house, having made one very great and highly honorific vow, to preserve him (Augustus) safe for all time, had performed the

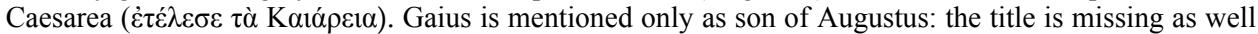
as any reference to his military roles and above all the epithet as Caesar, acquired after his adoption. Only in the last lines of the text there is a reference to sacrifices to be celebrated on the day when he was appointed consul (... "and later learning that Gaius, the son of Augustus, who was fighting against the barbarians for the safety of all mankind, was well and had avenged himself upon the barbarians, having escaped dangers, Scipio being overjoyed at such good news directed everyone to wear crowns and to sacrifice an ox for Gaius' safety, and was lavish in varied spectacles, so that what took place then rivalled what had come before, but the solemnity remained balanced; and he made a great effort, in leaving two days off of the days of Cesar's festival, to begin the sacrifices for Gaius on the day on which he was first designated consul; and he instructed us to observe this day annually with sacrifices and crown-wearing as joyously and ... as possible". Such reference is therefore prior to $4 \mathrm{AD}$, the year of Gaius' death, while the terminus post quem is $1 \mathrm{BC}$, when he was given the command for the eastern campaign. See ZETZEL, J. E. G.: New Light on Gaius Caesar's Eastern Campaign. GRByzS 11 (1970) 259-266. 
Gaius was, for example, mentioned in Eraclea by eponymous magistrates, ${ }^{26}$

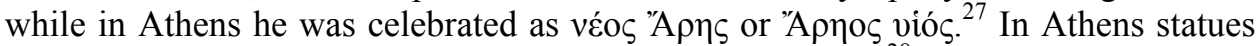

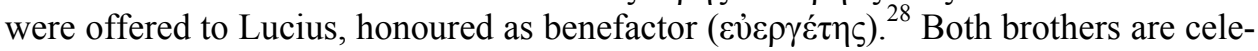
brated together with their mother Julia by the League of the officials of the Delphic

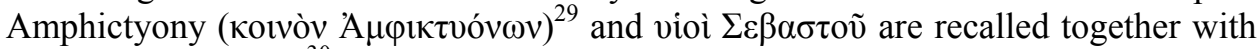
Augustus in Hypata. ${ }^{30}$ An arch-priest (’’ $\left.\rho 1 \varepsilon \rho \varepsilon v ́ \varsigma\right)$ prayed for Augustus, and for Caius and Lucius ${ }^{31}$ at Ammochostus in Cyprus. In Mitylene they were celebrated together with their younger brother, Agrippa Postumus and their natural father, M. Agrippa, defined as God, saviour, founder of the town $\left(\theta \varepsilon \delta \varsigma, \sigma \omega \tau \eta ́ \rho, \kappa \tau i ́ \sigma \tau \alpha \varsigma \tau \tilde{\alpha} \varsigma \pi\right.$ ó $\left.\lambda \operatorname{los}_{\varsigma}\right){ }^{32}$ The well-known dossier on Sardis, ${ }^{33}$ regarding the roles of Mesoghenes, includes the report of the delegation sent to Augustus who handed in the decree of the Sardis' council and people on the first day of Gaius' political career. This inscription dates back to $5 \mathrm{BC}$ and reports a series of celebrations which thereafter continued to take place on the anniversary of Gaius' reception of the toga virilis. This day was considered as sacred to the point where sacrifices and supplications for his soteria were made to the gods, and a statue of Gaius was placed in the temple of Augustus. Such extraordinary honours were perhaps excessive (considering that Gaius was only 15), although they ensured the emperor's benevolence towards the city. However, the fact that the League of the Hellenes in Asia and the People of the Sardians did not intend to pay homage only to the oldest of August' sons/grandchildren is clear from the following statement: "All people rejoice to see the united prayers ascending to Augustus

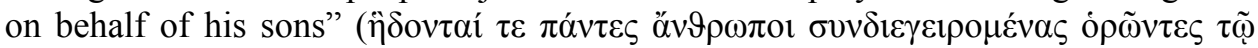

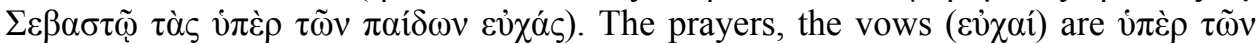

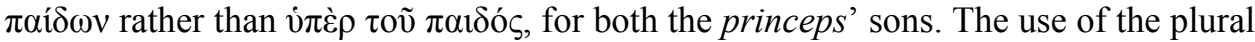
is paramount here, since Gaius in $5 \mathrm{BC}$ had a different position, as compared to Lucius. He became consul 5 years later, whereas Lucius was still a minor and his career was only in Augustus' vows.

What is significant in this sense is the oath of allegiance to Augustus that was taken in $3 \mathrm{BC}$ in Paphlagonia at Gangrae, the administrative seat, by delegates from all the cities of the region, and subsequently by all the Paphlagonians in their local communities: $:^{34}$ "In the third year from the twelfth consulship of the Emperor Caesar Augustus, son of a god, March 6, at Gangra the following oath was taken by the in-

${ }^{26}$ OGIS II 459.

${ }^{27} I G$ II 3. 3250; III 444; for Lucius, see $I G$ III 445, 446.

${ }^{28}$ IG II 3.3252 .

${ }^{29}$ SIG II 779.

${ }^{30} I G$ IX 2. $40=S I G$ II 778.

${ }^{31}$ EhrenBerg, V. - JONES, A. H. M.: Documents illustrating the Reigns of Augustus and Tiberius. Oxford 1955, nr. 115.

${ }^{32} I G$ XII 2. 168.

${ }^{33}$ IGRR IV 1756; BUCKLER, W. H. - ROBINSON, D. M.: Greek Inscriptions from Sardis. AJA 18 (1914) 312 ss.; EHRENBERG-JONES (n. 31) nr. 99; PRICE, S. R. F.: Ritual and Power. The Roman Imperial Cult in Asia Minor. Cambridge 1984, 66, 214.

${ }^{34}$ OGIS 532= ILS II 2. 8781. See SYME, R.: La rivoluzione romana. Introduzione di A. Momigliano. Trad. it. di M. Manfredi. Torino 1962, 477; LEVICK, B.: Augustus. Image and Substance. Harlow $2010,183-184$. 
habitants of Paphlagonia and the Roman businessmen dwelling among them: I swear by Jupiter, Earth, Sun, by all the gods and goddesses and by Augustus himself that I will be loyal to Caesar Augustus and to his children and descendants all my life in

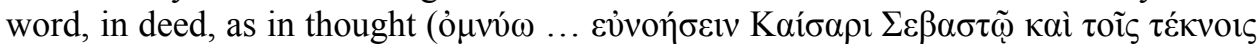

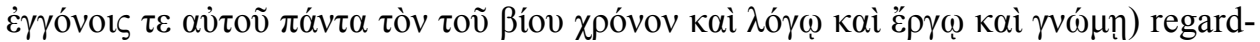
ing as friends whomever they so regard and considering as enemies whomever they so adjudge; that in defence of their interests I will spare neither body, soul, life, nor children, but will in every way undergo every danger in defence their interests...". Augustus' dynastic tendencies were very clear and Gaius and Lucius were openly identified as his future successors. The goodwill, the favour ( $\varepsilon$ v̌vol $\alpha$ ) is for $\Sigma \varepsilon \beta \alpha \sigma \tau$ ó $\varsigma$

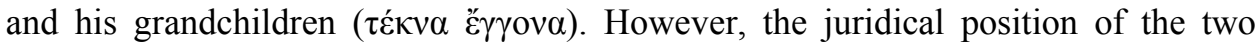
Caesars was not clearly defined in 3 BC; Gaius was consul designatus and princeps iuventutis; Lucius, who was under 18, could not take offices that senatus and the entire body of Roman knights had already granted to his oldest brother. However, Paphlagonians in their oath swore their loyalty to Augustus and to the imperial family and above all towards the emperor's heirs. All things considered, in 3 BC it seemed inevitable that Gaius and Lucius would become Augustus' heirs since Tiberius was relegated to Rhodes ${ }^{35}$ and Agrippa Postumus was still an infant. In the East there was no need for a precise and official designation for the emperor's succession. Gaius and Lucius had not received a true investiture de iure indicating the future positions that they were going to be given de facto. However, they were considered on all accounts to be Augustus' heirs. It remains to be seen whether they were considered as such only

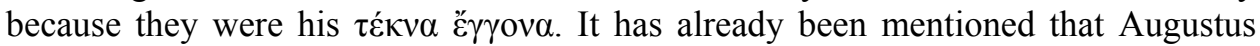
had felt the need to justify the high honours, bestowed on his sons and the positions that they had been given before the period provided by law, with the "merit provision" (he never recommended his sons for office without adding "If they be worthy of it") precisely because merit was the official condition to become magistrates. The question that should therefore be posed is what merits could they have, what valuable actions could a seventeen-year old and a fourteen-year old boys have carried out? Their official public appearances were always organized by Augustus and their public actions were equally coordinated by him. Despite the emperor's justifications, therefore, the two children had such positions only because they were his $\tau \dot{\varepsilon} \kappa v \alpha$. In the West, however, this could not be openly recognized, since the dynastic tendency, which coincided with the idea of the hereditary nature of public offices, conveyed a view that was the exact opposite of the Roman tradition ${ }^{36}$. In the East, on the contrary, the need

\footnotetext{
${ }^{35}$ On Tiberius' (voluntary?) exile to Rhodes and on the different dates regarding his return to Rome (before or after Lucius' death?) see Vell. 2, 99; Suet. Tib. 13. 2. See also NENCI (n. 2) 327 ss.

${ }_{36}$ Nevertheless an inscription from Conobaria dates back to $6 / 5 \mathrm{BC}$, containing Augustus' oath and to his children Gaius and Lucius: $A E$ 1988, 723. See GonZALEZ, J.: The first Oath pro salute Augusti found in Betica. ZPE 72 (1988) 113-127= AE 1988, 723, 11. 5-10: “... of my own volition I express my regard for the safety, honor and victory of the Emperor Caesar Augustus son of the Deified, pontifex maximus, and of Gaius Caesar, son of Augustus, leader of the youth, consul designatus, pontifex, and of Lucius Caesar son of Augustus, and of Marcus Agrippa grandsons of Augustus. I will take up arms, and I will hold as friends and allies the same ones I understand are theirs. And I will consider those to be my enemies, those whom I observe to be theirs. And if anyone does or plans anything against them, I will pursue
} 
to justify on the political or juridical level as legitimate the transfer of power from father to son was not felt. The oath of Paphlagonians testifies to such different approaches in the Eastern part of the empire towards Augustan dynastic trends.

Perplexities about the young age of the two Caesars were probably widespread. Ovid provides an indirect testimony of such perplexities through a long digression in the Ars Amatoria, where he celebrates the extraordinary command given to Gaius in the East with an enthusiasm that goes beyond adulation. ${ }^{37}$ Gaius' mission, in fact, was to re-establish the Roman influence in Armenia and persuade Phraates IV, king of the Parthians, not to interfere in Armenian issues. Gaius had thus a more diplomatic rather than military role (even though he was forced to fight Tigranes IV to place a philo-roman king on the Armenian throne). Ovid, instead, celebrated this mission as destined to subjugate the Parthian world with weapons ("Phartian, thou shalt pay penalty; rejoice, ye buried Crassi and ye standards that shamefully endured barbarian violence": Parthe dabis poenas; Crassi gaudete sepulti, signaque barbaricas non bene passa manus...), while inviting the young prince to claim Roma's rights, urging father Caesar and Mars to instil a divine fervor (numen), while prophesying future triumphs for him, who was now prince of the youth, but one day of the elders (nunc iuvenum princeps, deinde future senum), imagining the day when, dressed in gold, he would move forward before his enemies in chains and more verses would have celebrated his victories. I am not going to focus on the most likely imitatio Alexandri involved, according to a given interpretation, in Ovid's praise of Gaius hiding a badly covered polemics against certain "moderate positions" of the Augustan official propaganda in terms of foreign policy. ${ }^{38}$ The aim of the panegyric digression was not, of course, that of opposing Augustus to his young son, who, following the steps of Alexander, had started his military career there where in 53 BC the Battle of Carrhae had taken place. Ovid emphasized the strong parallel between Augustus and Gaius by arguing that "thy father and the father of the country hath girded thee with arms"

them to the death by land and by sea...". See GALSTERER, H.: Die Trauer der Städte um verstorbene Prinzen in der frühen Kaiserzeit. In FRASCHETTI, A.: La commemorazione di Germanico nella documentazione epigrafica. Roma 2000, 176. For another loyalty oath issued in the same years in Samos, see HerRmann, P.: Die Inschriften römischer Zeit aus dem Heraion von Samos [Mitteilungen des Deutschen Archäologischen Institut. Athenische Abteilung 75]. 1960, 68-81; HERRMANN, P.: Der römische Kaisereid. Untersuchungen zu seiner Herkunft und Entwicklung. Göttingen 1968, 95-98; RowE, G.: Princes and Political Cultures. The New Tiberian Senatorial Decrees. Ann Arbor 2002, 136-138.

${ }^{37}$ Ovid, who defines Gaius nunc iuvenum princeps deinde future senum, promises him more poems after his triumphant return from the Parthian challenge. The poet, taking as a pretext the sea fight for the inauguration of the Temple of Mars Ultor, and avoiding with a clear polemic intention any reference to military signs that Tiberius has brought back home in $20 \mathrm{BC}$, celebrated Gaius, who was leaving for his mission auspiciis animisque patris (Ars 1. 171-228). See PANI, M.: Roma e i re d'Oriente da Augusto a Tiberio (Cappadocia, Armenia, Media Atropatene). Bari 1972, 45-46; SyME, R.: History in Ovid. Oxford 1978, 8-15; SyME, R.: Roman Papers. Vol. I-V. Oxford 1979-1988, 923-924; BOWERSOCK, G.: Augustus and the East: the Problem of the Succession. In Millar, F. - SEgal, E.: Caesar Augustus. Seven Aspects. Oxford 1984, 171-175.

${ }^{38}$ The reason for Augustus' imitatio Alexandri "proprio perché troppo palesemente avrebbe evocato la rinuncia del principe a una guerra offensiva in Oriente era tema vietato dal regime" (BRACCESI, L.: L'ultimo Alessandro. Padova 1985, 56). See BRACCESI, L.: Livio e la tematica d'Alessandro in età augustea. In SORDI, M.: I canali della propaganda nel mondo antico, Milano 1976, 176-199. 
(induit arma tibi genitor patriaeque tuusque); ... "with the authority and experience of thy sire shalt thou, $\mathrm{O}$ youth, make war, and with the experience and authority of thy sire shalt thou conquer" (auspiciis animisque patris, puer, arma movebis et vinces animis auspiciisque patris...). Gaius left therefore under Augustus' auspices. Plutarch, in one of the sayings published in the leaflet "About the Fortune of Roman" reports that "by sending his grandchild to Armenia, the princeps asked the gods to accompany Pompey's wisdom, Scipio's audacity and his own fortune". ${ }^{39}$ However, it was necessary to reassure those who had perplexities and insecurities about the lack of experience and the young age of the person who had been given the vengeance (ultio) of the Roman eagles: "valour falls early to the lot of Caesars" (Caesaribus virtus contigit ante diem), as Ovid claims in this sense. Despite his young age, he was accompanied by his father's auspices and he possessed, almost as a genetic transfer, the virtus typical of the Caesars. This made him fence, guard of Rome $(\varepsilon \rho \rho \mu \alpha)^{40}$ and Antipater of Thessalonica's courtesan pen paid tribute to the Parthians who fled at the news that a leader was approaching who had been provided by the gods with wisdom, strength, lack of doubts and fears.

Adulation by some poets and the natural adoption of the dynastic model by subjects in the eastern part of the empire seem to have almost anticipated and foreseen Augustus' attempts to identify guidelines for his own successions. Adoption (which is worth recalling was not used as an institution before $17 \mathrm{BC}$; in fact both Marcellus and Drusus were largely facilitated in their careers and were particularly close to Augustus, but weren't adopted) to appoint the heirs of the power and abbreviation of the period as provided by law to be appointed to the most important offices were the only political means to this end, since a legal solution was not available yet. The princeps, however, when addressing Gaius, who was in Armenia and with whom he had correspondence through a code book, ${ }^{41}$ fearing that he was being controlled, clearly

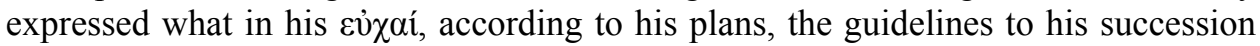
were: with the help of the gods, as previously argued, he hoped he could transmit (traducere) his own statio to his young children who were demonstrating their merits. An appointment which undoubtedly conferred a privileged position on his heirs, while having a moral value and practical efficacy, was nevertheless legally non-binding. ${ }^{42}$ After all, Augustus' princedom has always moved in such institutional uncertainty, in

\footnotetext{
${ }^{39}$ Plut. Mor. 319e. On the absence of Caesar as a model, see BRACCESI, L.: Giulia, la figlia di Augusto. Bari 2012, 78-79.

40 Anth. Pal. IX 59, 297.

${ }^{41}$ Suet. Illus. fr. $107 \mathrm{R}$.

${ }^{42}$ DE MARTINO (n. 1) IV 1, 403 ss. This does not mean, however, the private citizens could not offer dedications to young princes with clear flattering tones. See GASPERINI, L. - PACI, G. (a cura di): Nuove ricerche sul culto imperiale in Italia. Atti dell'Incontro di Studio, 31 gennaio Ancona 2004. Roma 2008. Acerra's incomplete inscription is problematic in this sense (CIL X 3757): see LETTA, C.: Il culto pubblico dei Lares Augusti e del Genius Augusti in una dedica metrica da Acerrae. RCCM 44 (2002) 3543; BITTO, I.: Alcune osservazioni su un carmen epigrafico da Acerra. In CALTABIANO, M. - RACCUIA, C. - SAntAgAti, E. (a cura di): Tyrannis, Basileia, Imperium. Forme, prassi e simboli del potere politico nel mondo greco e romano. Giornate seminariali in onore di S. Nerina Consolo Langher. Messina 2010, 401-413.
} 
a grey area where reality and appearances were blurred to the point of becoming undistinguishable. In a well-known passage of the Res Gestae ${ }^{43}$ he argued per consensum universorum potitus rerum omnium, or potens o potiens, ${ }^{44}$ according to the latest suggestions after the recent founding of the new fragment of the Monumentum Anti-

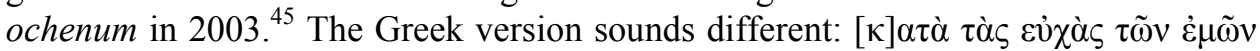

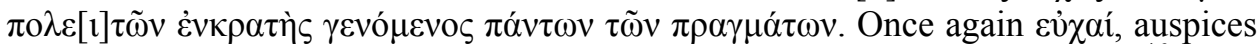
which in his case came true. For Gaius and Lucius, instead, an atrox fortuna ${ }^{46}$ made such auspices remain a desire in the memory of what was an old princeps by then.

\author{
Elena Caliri \\ Dipartimento di Civiltà Antiche e Moderne \\ University of Messina, Italy \\ ecaliri@unime.it
}

${ }^{43}$ Potitus, as commonly known, is the integration proposed by MoMmSEN, TH.: Res Gestae Divi Augusti. Berlin $1883^{2}$, 146. Status quaestionis in SEYFARTH, W.: «Potitus rerum omnium». Ein Beitrag zur Deutung der RGDA Kapitel 34. Philologus 101 (1957) 318 ss.; KRÖMER, D.: Textkritisches zu Augustus und Tiberius (Res Gestae c. 34 - Tac. Ann. 6, 30, 3). ZPE 28 (1978) 127-144; Res Gestae Divi Augusti. Texte établi et traduit par J. SCHEID. Paris 2007, 85 ss.; NicosiA, G.: Potens rerum omnium. MEP 12-15 (2009-2012) 213-230.

${ }^{44}$ See COSTABILE, F.: RG 34.1:«[POT]IENS RE[RU]M OM[N]ium» e 1' "Edictum de reddenda re publica". In Revisione ed integrazione dei Fontes Iuri Romani Anteiustiniani - FIRA, Studi Preliminari. Vol. I. Torino 2012, 35-81.

${ }^{45}$ BOTTERI, P.: L'integrazione mommseniana a Res Gestae 34, 1 e il testo greco. ZPE 144 (2003) 262 ss.; Drew-BEAR, T. - SCHEID, J.: La copie des Res Gestae d'Antioche de Pisidie. ZPE 154 (2005) 233 ss.

${ }^{46}$ Suet. Tib. 23. 